\title{
From Contest State to Patronage Democracy The Longue Durée of Clientelism in Indonesia
}

\author{
Henk Schulte Nordholt
}

To seek a protector, or to find satisfaction in being one these are things common to all ages.

BLOCH 1964, I:147

Indonesia's political landscape is currently inhabited by a large number of civil militias. In Jakarta the biggest militia is the Betawi Brotherhood Forum (FBR) which claims to have a membership of 80.000 people. Competing militias include Forkabi, or Forum Komunikasi Anak Betawi, the Pemuda Pancasila and more than 130 other groups (Wilson and Nugroho 2012; I. Wilson 2012). The existence of militias is not restricted to Jakarta but seems to be a nationwide structural phenomenon. To give a few examples: in Bali Forum Peduli Denpasar (FPD) and Laskar Bali used to dominate the informal security networks of the city of Denpasar, while more recently the Baladika Bali, claiming a member ship of 17.000 people, made its appearance (H. Schulte Nordholt 2007; Wilson and Nugroho 2012). In Kalimantan (Bakker 2009a; 2009b) the Dayak Adat Defence Command is the biggest militia claiming to represent the interests of the Dayak communities, while on the adjacent island of Tarakan various migrant communities have their own militias (C. Wilson 2012). These are just a few examples.

Centered around a charismatic leader and with a membership that is often based on ethnicity, these militias claim to serve the interests of local society and seek to maintain relationships with political leaders. Their semi-military outfits are very similar to the way criminal strongmen (preman) operating under the New Order were dressed, and underline the intimidating public appearance of these groups. On the other hand, these militias present themselves as civil society organizations addressing issues like security, social justice, employment, and cultural identity. Many of them are officially registered as mass organizations while they are at the same time involved in illegal activities. Operating in the borderlands of the formal state and rooted in local society they enjoy considerable public support.

In Jakarta FBR claims to represent the interest of the urban poor by resisting evictions of slum dwellers, providing security, and seeking to improve employment opportunities and health facilities for the Betawi population of Jakarta.

(C) HENK SCHULTE NORDHOLT, 2015 | DOI 10.1163/9789004288058_012

This is an open access chapter distributed under the terms of the Creative Commons Attribution-

Noncommercial 3.0 Unported (CC-BY-NC 3.0) License. 
In Bali the FPD and Baladika Bali present themselves as guardians of traditional Balinese culture against the evils of globalization in general and Javanese thieves in particular, while in Kalimantan the Dayak Adat Defence Command intervenes in land disputes and seeks to obtain lucrative construction contracts. Nearly all militias are involved in election campaigns of political parties, maintain informal relationships with the police, while they receive protection money from café's, restaurants and bus terminals.

The public appearance of many militia leaders reminds one of the 'men of prowess' who once inhabited the fragmented map of small-scale politics of Southeast Asia, and maintained vertical relationships with clients and political power holders (Wolters 1982). Is this just a superficial resemblance or can we trace a continuity stretching from pre-colonial times to post New Order politics in which strong men and clientelism feature prominently? If militias are part of a long historical trajectory going back to the days of the pre-colonial 'contest state', to what extent do their efforts to provide security and justice reveal certain 'statelike qualities' which can also be attributed to their ancestral men of prowess? If we can trace a longue durée of clientelist relationships that characterize(d) Indonesian politics, what does that tell us about the present state of citizenship?

In this essay I aim to trace clientelism as a defining feature in Indonesian politics within shifting historical contexts. I will apply the notion of the longue durée as a means to overcome the conceptual discontinuities, which are produced by conventional historical periodization. ${ }^{1}$ However, in doing so, I do not intend to uncover hidden - and timeless - structures. When Braudel (1980 [1958]) launched the concept of the longue durée in his famous essay 'History and the Social Science', he explicitly responded to Claude Levi-Strauss (1968 [1949]) who had suggested that we need to eliminate time in order to discover the elementary structures that organize our way of thinking. Braudel argued that only through the measurement of time (i.e. the durée) the nature of structures can be identified. He was less clear about the interaction between the various layers of time he had identified, and the extent to which an underlying longue durée is affected by cyclical movements and sudden events. By following Peter Boomgaard's approach (2001a) to Southeast Asian history and applying a longue durée perspective with regard to key political relationships it is possible to overcome the compartmentalization of historical periodization.

1 I am certainly not the first to do this. Apart from Boomgaard's work in economic and ecological history, and other colleagues in this volume, Day (2002) attempted to trace cultural continuities in processes of state formation in Southeast Asia, while Lieberman (2003, 2009) wrote an impressive history of slow processes of state formation between 800 and 1830 in a wider comparative context. 
For, each historical period tends to have certain ascribed characteristics in combination with a particular analytical vocabulary and a specific perspective owned by an authoritative group of experts, which obscures underlying structures and persistent patterns in Indonesian history such as clientelism.

\section{Lords, Followers and the Enigma of the Pre-colonial State}

As Anthony Reid (1988) and many others (cf. J. Scott 1972) have demonstrated, vertical bonds connecting lords and followers, or patrons and clients, permeated everyday life in pre-colonial Southeast Asia. In the absence of large centralized states, a multitude of lords provided protection and patronage in exchange for loyalty and labour, and surplus and support during wartime. Control over manpower was a vital index of power and status (Reid 1988:129). Because land was abundant but manpower scarce, labour was highly valued and often tied to power holders through debt bondage. Indebtedness was a key mechanism that made clientelism work. Debt relationships were not only imposed by the powerful through punishment, indebtedness, slavery, or the obligation to pay bride wealth, but were also actively sought by the less powerful. Indebtedness was a form of insurance because patrons were obliged to offer protection, while the absence of protection made people extremely vulnerable. Patron-client relationships were personal and intimate and therefore often phrased in kinship terms (Day 2002). Clientelism conceptualized as father-son relations implied a natural hierarchy which could not be denied or contested. Both patrons and clients needed each other's support. Patrons were in constant competition with (near) equals, both among the aristocratic elite as well as at the local level, and clients were supposed to defend their patron's honour.

Michael Adas (1981:218) has characterized the dynamics of patron-client relationship in a context of ongoing competition as a 'contest state':

Central to this form of political organization is rule by a king of emperor who claims a monopoly of power and authority in a given society but whose effective control is in reality severely restricted by rival power centres among the elite, by weakness in administrative organization and institutional commitment on the part of state officials, by poor communications, and by a low population-to-land ration that places a premium on manpower retention and regulation. These conditions give rise to polities in which there was a constant struggle between ruler and nobility, between factions of the elite at various levels, and between supravillage elite groups and village notables and peasants for the control of 
labor and agricultural production which formed the basis of these predominantly agrarian states. Although the fortunes of the contending parties fluctuated greatly over time, their continuing struggle over revenue control and the inability of any of the parties to dominate the others decisively on a sustained basis suggest the concept of the contest state as a useful way to characterize this form of political organization.

Clients had a relatively strong bargaining power because patrons ultimately depended on their loyalty, which could not institutionally be enforced. Avoidance - not showing up, seeking the protection of another lord, or migration - was therefore a powerful 'weapon of the weak'.

Evidence from Bali confirms this general picture. The Balinese poem Bagus Diarsa expressed the special nature of lords and followers in through the metaphor of the herdsman and his cattle:

subjects are like cattle, their shepherd is the Anak Agung [lord, lit.: 'big man'].

When he feeds them well they are fat, their horns are pointed and sharp, who dares to molest them? It is foolhardy to do so! But when the herd is hungry, their flanks fallen in, they will travel in unwavering line wherever grass is found in abundance. If they wander they will be taken; What price will be the ransom? It is the herdsman who is the fool then; he is his neighbours' laughing stock.

H. SCHULTE NORDHOLT 1996:35.

Leaders had to motivate and persuade followers to accompany them to the battlefield. Another source tells how this was done (Worsley 1972:157-159). First, followers were given food and drinks, clothing, weapons and women. Then it was the king's turn to ask to follow him to defeat the enemy and gain wealth and status. Warfare reinforced the system as it urged people to seek protection and challenged strong men to demonstrate their prowess.

Another Balinese poem, the Kidung Nderet explains what happened when a lord ignored his obligations towards his followers and started to 'forget' them (H. Schulte Nordholt 1993). When new favourites of the king rose to power and trusted followers lost their well-deserved privileges, internal disputes emerged 
which weakened the bonds of loyalty on which the king's authority rested. Tensions increased when external enemies took the opportunity to attack and confusion and chaos prevailed. Lesser lords no longer supported the king who faced a humiliating surrender. The lesson of the poem is that when leaders start to forget, the kingdom falls apart which leads to confusion and destruction.

Evidence from South Sulawesi and the Malay world confirms that local politics were informed by similar dynamics. Clientelism formed the core of political dynamics in South Sulawesi. Basic to this system was the awareness that the higher had authority over the lower, an authority that was accepted by the latter and conjoined by the understanding that high and low needed each other to enhance their prestige (Chabot 1950:102). Clientelism covered a wide field of activities, ranging from warfare, hunting, and rituals, to agricultural and domestic work, and trade. A leader's responsibility was to protect and feed his followers, to show generosity and display eloquence and bravery, while clients were expected to support their lords and defend their honour (Pelras 1996:181$186,2000)$. In the Malay world everything depended on ties of loyalty that connected the king with various groups of followers. Loyalty and treason were two key words in important texts like the Sejarah Melayu and the Hikayat Hang Tuah which dealt with kingship and hierarchy (Andaya and Andaya 2001:46$5^{2}$ ). A well-known metaphor - similar to one from Bali - explained that subjects were like roots while the ruler was the tree; without roots the tree could not stand upright (Andaya and Andaya 2001:49). The king's position depended on the acceptance of his subjects, and he was expected to consult his ministers before taking a decision, but the biggest sin servants and subjects could commit was treason. It was better to be killed by the king while innocent than to betray him.

In the nineteenth century, when in Europe the bureaucratic nation-state emerged, western observers who tried to understand the nature of 'the state' in Southeast Asia were confronted with an enigma. Envoys sent to Bali in 1840 observed the following:

Since my first arrival here, I had given myself the task of gaining a picture of the relationships between the rajas [kings]...furthermore about the way of their government, their power etc. The more I learned about it, the more I noticed that I became entangled in a labyrinth of complex family relations and interests. All this became even more complicated by the divergence of information, which was given differently, as one received it from [representatives of various] royal lineages...or anyone else.[…] 
Everything here is chimerical, nothing clear-cut; every day the most blatant contradictions supplant each other.

H. SCHULTE NORDHOLT 1993:291.

'States' consisted of networks of personal relationships, which were hierarchically ordered and often expressed in (extended) kinship terms. The centrality of the king, or raja, is illustrated by the Malay term kerajaan, which means: the condition of having a king. ${ }^{2}$

There is of course a clear overlap between the metaphor of the family and the Weberian model of patrimonialism. The family metaphor included important notions of origin and offered a model for a hierarchical order in which the core lineage of the king, ideally descending in a direct line from a divine ancestor, formed the centre while affiliated kin groups formed the lower periphery. Marriage and concubinage were key instruments to knit this system together. Origin and hierarchy were expressed in rituals for which large numbers of followers were mobilized and where the worlds of gods, ancestors and men were connected (Geertz 1980). Origin, hierarchy and rituals cannot be separated from personal charisma and the power of the king. Without strong leadership kingship was invisible, which in turn made the kingdom fragile. Seen from the perspective of the clients, royal patrons were not only expected to provide protection against visible enemies, but also against invisible dangers that threatened the continuity of life, like bad harvests, plagues and natural disasters. The notion of potency reflected in this respect both the power of the king and his role to enhance the fertility of his realm. The most important achievement of a successful king was not a destructive display of force but his ability to control violence (H. Schulte Nordholt 1996:143-158).

\section{Continuities and Criminality under Colonial Rule}

If we continue this quick, and necessarily superficial, historical overview, the next series of snapshots concerns the colonial period. In the course of the nineteenth century the Dutch gradually build a colonial regime in Java. After they had dismantled the most important royal centres, they spread a thin layer of western institutions over a society that was still dominated by patron-client relationships. Dutch colonial rule was in administrative terms cost-efficient while it produced economically a profitable surplus. The secret of this success was a system of indirect rule which tied the interests of the Javanese regional

2 Milner (1982:114); $c f$. Day (2002:38-39); Nagtegaal (1996:52); Wolters (1982). 
elites to the needs of the colonial regime. Both the backing by and the incentives from a strong colonial centre strengthened the position of the regional Javanese elites who were expected to maintain peace and order and to facilitate the economic exploitation of Java by giving access to land and mobilizing manpower. The Javanese elites were clients of the Dutch but at the same time powerful patrons within their own domains. As long as they managed to guarantee peace and colonial prosperity the Dutch did not intervene in local affairs which offered the Javanese elites opportunities to strengthen their regional power. Moreover, since the Dutch made an end to endemic warfare, which had characterized the old contest state, the Javanese elites were no longer threatened by neighbouring competitors.

Under colonial rule clientelism was reproduced but the conditions as well as the precise relationships between patrons and clients had changed. As their position became stronger the Javanese elites distanced themselves from ordinary peasants. An important intermediate role was played by village elites who became the principal clients of the regional elites, while they emerged at the same time within villages as strong local patrons. Both regional and village elites strengthened their position while ordinary clients became more dependent as their bargaining power weakened. A combination of population growth and the ongoing clearance of uncultivated land, which left the population less and less place to hide, resulted in a gradual immobilization of the village population (Boomgaard 1989a; Hüsken 1988, 1994). There were, in other words, fewer opportunities for avoidance protest, which had characterized the old contest state. Instead, protest took the form of violent confrontations which were relatively easily suppressed by powerful colonial forces.

Not all members of the Javanese elite had survived the transition to colonial rule. The Dutch had reduced the number of regional power holders and had virtually abolished an intermediate level of go-between leaders just above the village level. Seen from a formal colonial perspective large districts were now run by a small number of administrators who directly dealt with their village heads. In reality something else happened. The vacuum that had been created by the Dutch was filled by an informal network of strong men cum criminals, or jago, who operated in a twilight zone. They were used as strong arm and spies by the regional power holders to keep their district under control and they also cooperated with village heads to mobilize labour and to collect taxes. At the same time they were involved in theft, cattle rustling and opium smuggling, while they presented themselves also as local strong men able to protect their village against other jago (Schulte Nordholt and Van Till 1999). In their capacity as local power brokers they were sometimes also potential sources of unrest. 
In the eyes of the Javanese population the real embodiment of everyday colonialism were not the Dutch who resided in distant places, but the village headmen in tandem with the local jago. For them colonialism and criminality were to a large extent synonymous. The Dutch were to a large extent unaware of the kind of criminality they had helped to create. Javanese regional elites, village headmen and jago were all descendants of the old contest state. Their relationships had changed since they were incorporated into a colonial regime. Despite these changes clientelism remained a defining feature of rural Java.

Around the turn of the twentieth century large areas outside Java were incorporated into the Netherlands East Indies. Most of these newly conquered areas were brought under indirect rule. As in Java, regional aristocracies played a key role in redefining old patron-client relationships under the new colonial regime. Protected by the Dutch, members of the old aristocracies became more powerful than before in their new roles in which they were expected to give colonial rule a traditional face.

The Dutch colonial regime presented itself increasingly as a well-integrated administrative and a-political bureaucracy, or beambtenstaat (Benda 1966), consisting of 100.000 employees ( $15 \%$ of whom were Europeans) who managed a colony inhabited by 60 million people. However, colonial peace and order was not in the first place based on a small and seemingly efficient bureaucracy, but rested primarily on a myriad of informal patron-client relationships which ultimately connected the centres of Dutch rule with Indonesian society.

\section{The Post-colonial Nation-state and the Triumph of Patronage}

Revolution and independence created important fault lines because the rise of the new nation-state was accompanied by the emergence of new research centres and new academic paradigms. Initially emphasis was laid on processes of nation-building and national integration, after which the emergence of the strong developmental state and received more attention. These ruptures obscured underlying continuities.

As Herbert Feith $(1962: 406,423,463)$ indicated in his monumental book on Indonesian politics in the 1950s, attempts to establish a parliamentary democracy were seriously undermined by increasing levels of corruption. Due to rising inflation government salaries went down, which invited bureaucrats to engage in illicit activities, while political parties channelled funds to their own constituencies, which in turn stimulated a process of pillarization of Indonesian politics. This process was reinforced during Guided Democracy (1959-1965) when the national parliament was side-lined by President Sukarno who then 
headed a patrimonial system characterized by factionalism and intrigues (Crouch 1979). At the top Sukarno tried to maintain a precarious balance between rival groups (communists, Muslims, nationalists), which commanded each a large following in society, while the military formed yet another interest group. The demise of Guided Democracy occurred in 1965 when the military came to power and eliminated the communist party. The end of Guided Democracy and the mass killings of communists marked also the triumph of clientelism.

Carl Lande (1964) was the first social scientist who explicitly applied a patron-client model to Southeast Asian politics to explain the absence of classbased voting the Philippines, while Manning Nash (1965) did a similar analysis in northern Burma. In a general article on the relevance of investigating patronage in Southeast Asia James Scott (1972) indicated that patron-client relationships had survived due to the absence of firm impersonal institutions which guaranteed personal security, while inequalities in society increased because both state institutions and political parties tended to bet on the strong in order to secure support. However, the nature of patron-client relations had changed: relationships tended to become less affective and personal and more instrumental and office based. At the same time chains of patron-client relationship were stretched through political party lines from regional setting towards the capital.

In Indonesia a serious attempt was made to dismantle these chains of patronage and their concomitant social inequality. We follow these efforts in the context of a small provincial town in eastern Indonesia. ${ }^{3}$ During the colonial period local rajas had benefitted from the Dutch strategy to bet on the strong in order to establish stable and cheap indirect rule. Due to the Dutch support the gap between the rajas and their client-subjects had widened. After independence the privileged position of many rajas came under attack because the ideology of the new nation-state no longer tolerated old fashioned feudal practices. As a result the power of rajas declined while the new national leaders started to bet on the emerging educated urban middle classes. From this group new local bureaucrats and party leaders emerged who became clients of political patrons at the national level. Employed by the state and with good upward connections with national party bosses they created new and often ethnic based networks of clients at the regional level. They derived their main income from rent seeking through their involvement in state interventions in the local economy.

3 I base this paragraph on new and innovative research by my colleague Gerry van Klinken (2014) on the history of Kupang on the island of Timor. 
In this context the Dutch term kattebelletje (incorrectly quoted in Feith 1962:479 as 'kaart belletje') emerged. It refers to a brief informal memo by a patron which gives a client of his access to funding, a job etc. The term slipped into the national language as katebelece and resurfaced, for instance, in 1994 in the publicity about the Bapindo corruption case when retired general Sudomo wrote an informal note of support for businessman Eddy Tansil. ${ }^{4}$

In Kupang, the new rent-seeking provincial urban middle class represented a conservative force that allied itself with local businessmen and church leaders. Their position was not uncontested because from the late 1950s onwards the communist party (PKI) gained mass support in its efforts to break the chains of patronage and to spread the idea of equality. As elsewhere in Indonesia the PKI targeted especially the so-called kabir (capitalist cum bureaucrats). Apart from a growing sense of class consciousness this campaign involved also a new cross-class alliance of progressive middle-class politicians - many of whom were school teachers - with the rural poor.

In terms of actual achievements the results of the PKI campaigns were modest. Its most important contribution was perhaps that it spread the message of modernity by emphasizing progress and equality and by that the promise of a new world that had liberated itself from patrimonial forms of inequality. In the words of one of the party leaders, Njoto: 'We are the men who are modernizing life in the villages; we are the men introducing the twentieth century' (Mortimer 1974:409). Modernity transpired also in the way the PKI was organized. The party was very advanced in organization-building applying universal standards of recruitment, promotion by merit, specificity of roles, a recognized hierarchy of authority and applying uniform roles of control and checking. Observers were struck by the business-like attitude of PKI cadres and the high standards of performing tasks, sowing among its followers seeds of selfconsciousness and self-activity. As such the PKI was an important vehicle for merit-based advancement and offered ample opportunities for young talented people (Mortimer 1974:407-410).

It remains of course to be seen to what extent the PKI would have succeeded in making 'a new world' which was no longer dominated by clientelism, but mass murder made and untimely end to these ambitions. Nation-wide more than half a million supporters of the PKI were killed, 6000 of whom lived in the east Indonesian province Nusa Tenggara Timor. It was not by institutional strength, let alone by the rule of law, but through new patronage networks with a new middle class, that the state managed to keep the country together and to reach deep into society (Van Klinken 2014).

4 Editor, 24-3-1994. 


\section{Strong State and Patronage Networks}

Since the middle of the 1970s the rise of the strong centralized state became the dominant theme in many writings on Indonesia. The New Order under President Suharto was described as an authoritarian developmental state, which succeeded to generate sustained economic growth. Richard Robison (1986) was among the first to apply a political economy approach and identified the bureaucratic state as the main motor of capitalist development and the breeding ground of a new capitalist class. In line with a renewed interest in the state (Evans et al., 1985), Benedict Anderson (1983) emphasized in a paradigmatic article also the autonomous role of the state while he pointed at striking similarities between the New Order regime and the late colonial state. Blinded by its economic success - and less critical than the Cornell scholars around Anderson - an increasing number of economic observers - located among others at the Australian National University - were inclined to see the New Order as a rather well-integrated set of institutions that operated apart from society and facilitated ongoing economic growth and de development of a relatively free market (H. Hill 1996).

Harold Crouch $(1979,2010)$ represented at Monash University a more critical approach towards the seemingly coherent nature of the New Order state, and emphasized the patrimonial nature of the regime. ${ }^{5}$ According to him, the bureaucracy was in practice overstaffed, underpaid, largely incompetent, with overlapping tasks and few responsibilities, whereas patronage distribution was the glue that held the system together (Crouch 2010:17). Compared to his predecessor President Suharto had more money to distribute which he derived from oil revenues and foreign aid. This enabled him to control various factions among the elite (military, business, bureaucrats) by granting licenses, access to projects, credit and jobs in exchange for loyalty. A pyramid of patron-client relationships ran down from the presidential palace to the villages, while the entire bureaucracy was permeated with officially encouraged corruption in the context of which government party Golkar operated as a nation-wide patronage network (Crouch 2010:161). There was an informal system of taxation by which bureaucrats supplemented their modest salaries with selling of licenses and levying personalized forms of taxation. In a similar vein the military, whose budget was only partly covered by the state budget, gathered their own funding through business activities and security services.

The extended network of patronage relationships was hidden behind a façade of elaborate bureaucratic procedures and a carefully orchestrated public

5 Dwight King (1982) combined both the bureaucratic and patrimonial nature of the regime. 
display of order and unity. National elections were part of this public appearance of order. It was not results that counted but the orderly progress of the campaigns which had to prove that the regime was in control (Pemberton 1986).

At the village level local elites were incorporated in the patronage network of the regime. In exchange for development projects and access to other state resources village leaders were made into clients of the New Order while they were enabled to enhance their role as local patrons. ${ }^{6}$ Suharto deliberately emphasized his patrimonial role as 'father of development' by a special development program called Inpres (Presidential Instruction), which suggested a personal involvement with particular projects. Frans Hüsken (1994) observed that towards the end of the 198 os the old village elite in his research area in Java retired and was succeeded by representatives of a new emerging middle class who aspired further upward mobility by gaining access to state resources.

Outside Java, similar processes took place. Pelras (2000:330-334) observed that in South Sulawesi patron-client relationships underwent changes. The old patrons with an aristocrat background were replaced by new educated entrepreneurs who gained wealth in trade and fishing and developed helpful connections with state officials. One of the most successful among these was the Kalla family from Bone. Father and son made a fortune in trade and expanded their business empire trough lucrative government licenses. In 2004 the son, Jusuf Kalla, even became vice-president of Indonesia.

The New Order regime rested ultimately upon violence and intimidation and made use of semi-official militias and informal connections with criminal gangs to harass its opponents. Seen from a long-term perspective one can identify the criminals operating under the umbrella of the New Order as the grandchildren of the rural jago in nineteenth-century Java (H. Schulte Nordholt 2002).

\section{Patronage Democracy and Fragmented Citizenship}

The monetary crisis that hit Southeast Asia in 1997 paralyzed the patrimonial networks in Indonesia and caused a serious congestion in both the downward flows of material rewards and the possibilities of upward mobility (Sidel 1998). Economic crisis, nation-wide student protests and discord among the elite eventually caused the fall of President Suharto in May 1998.

6 Antlöv (1994); Hüsken (1988, 1994); N. Schulte Nordholt (1982, 1987). 
In a very short period of time Indonesia experienced a transition from a centralized authoritarian regime to a decentralized electoral democracy, while the strong state seemingly gave way to the emergence of a strong civil society. However, regime change was not accompanied by the breaking up of clientelism because opposition groups were too weak and divided to press a common reform agenda and although old patronage networks were partly in ruins, many factions of the old regime managed to survive under new circumstances (Crouch 2010; see also Hadiz and Robison 2004). Ultimately the threat of mass unrest from below stimulated timely enough elite solidarity to maintain the basic structures of the old regime. As a result reform measures were allowed as long as these did not fundamentally threaten the vested interests of the elite (Slater 2010:48-50).

At the national and the regional level new forms of patronage emerged, which were headed by unstable alliances of businessmen, bureaucrats and politicians. Due to a far reaching process of decentralization more money flowed to the regional level regional where competing elite factions tried to control these. Contrary to the Philippines where regional dynasties gained a monopolistic position over coercive and local economic resources, regional leaders in Indonesia remained dependent on state resources and vulnerable to electoral changes, and sometimes judicial investigations (H. Schulte Nordholt 2012).

Direct elections created a patronage democracy in which leaders derived their power mainly from the state and maintained relationships with their constituency through clientelistic practices, while their clients identified themselves mainly in local, and often ethnic, communalist terms (Van Klinken 2009:145). At the regional level we can identify the formation of a political class (Vel 2008) consisting of those who dominate regional politics and control access to economic and financial resources of the state which they share with allies, relatives, and clients. A case in point is the rise of the Limpo family in South Sulawesi. Born in an aristocratic family the father started his career in the 1950s in the army, in a time of civil war in South Sulawesi the most powerful institution. Under the New Order he moved into the civilian administration of the province and became active in Golkar while he was also involved in various business ventures. His children followed his footsteps. His son started as a subdistrict administrator and worked his way up in the bureaucratic hierarchy. When he was arrested in 2001 for drugs abuse his career seemed to be over, but the next year he made a remarkable come-back when he was elected vicegovernor. In 2007 he was elected governor. Backed by a private security force of thugs he is now heading a wide informal network of business allies and clients. 
Decentralization produced on the one hand more state at the regional level, but created also a new polycentric ensemble of power centres. Patronage obstructs in this context a discourse on class differences and does not question inequality. What, then, are the effects of decentralization and patronage democracy on the notion of citizenship?

Ideally liberal citizenship should be seen as the result of a formal relationship between the state and its citizens which is defined in terms of mutual rights and obligations as regulated by the rule of law. Democracy guarantees the accountability of the state while citizenship makes democracy work and vice versa. What happens to citizenship in weakly institutionalized states dominated by clientelism? Seen from an ideal typical definition of liberal citizenship clientelist systems are often defined as 'messy', 'failing' or 'soft'. This approach emphasizes the incapacity of states to maintain the rule of law but fails to explain why so many people profit from these incapacities (Van Klinken and Barker 2009). The answer can be found in the embeddedness of the state in society which forms the breeding ground of many patron-client relationships. Despite important political reforms and a well-functioning electoral democracy, central features of the old patron-client system remain firmly in place in Indonesia because clients prefer strong patrons who deliver more than the weak and unreliable rule of law of an abstract and often distant nation-state. The embeddedness of the state in society reveals also the extent to which middle classes support the image of a coherent state while they seek at the same time access to its resources through personal connections.

To understand the fragmented nature of citizenship in Indonesia it is helpful to follow an alternative approach to the idea of the state from the perspective of the citizen as suggested by Christian Lund (2011). According to Lund, the state defines and guarantees two constituting elements of citizenship: identity and property. Not all government institutions deliver this; hence not all government institutions have state-like qualities. Instead of a fixed set of institutions we should see the state as a relational and often fragmented quality determined by the extent to which certain institutions have the authority to define and guarantee identity and property rights in exchange for which this authority is recognized as legitimate. Citizenship is established by this mutual recognition. Hence, " $[w]$ hen different institutions attempt to govern with state quality, competing processes of consolidation and erosion of institutions of political authority, of formalisation and informalisation of rule, and dynamics of exclusion and inclusion of people unfold' (Lund 2011:75).

In Indonesia many government institutions lack state qualities as a result of which we can observe a fragmentation of citizenship, which produces insecurity. Against this backdrop we now return to the question why militias are so 
popular. Resembling NGO-like legal entities, militias maintain close ties with power holders and emphasize their role as providers of security which is accompanied by the prominent role of strong men in combination with a military outlook. Instead of threatening the existing order militias claim to support the system while they also claim to represent the interests of their constituencies. Key words dating from the Orde Baru, antisipasi and koordinasi, are still used and indicate the ever present threat of disorder and insecurity which should be contained in time. Local society is seen as a vulnerable space constantly threatened by outsiders - Madurese migrants are seen as threatening Betawi inhabitants of Jakarta; in Kalimantan Dayak feel threatened by immigrants; 'Islam' threatens Balinese culture (Wilson and Nugroho 2012). In the absence of a strong rule of law embodied in stable government institutions, successful militias have in this context certain state-like qualities by offering security, confirming ethnic (or religious) identities and defending property rights. And they are likely to stay because they are an integral part of the political system. In this respect militias are also part of a longue durée of patronclient relationships running from the contest state to current militias, be it through different institutional 'geographies'. 